\title{
Change of Mining Business Working Agreements into Special Mining Business Licenses Under the Indonesian Mining Law
}

\author{
Hanif Nur Widhiy anti \\ Faculty of Law \\ Universitas Brawijaya \\ Malang, Indonesia \\ hanif.nur@ub.ac.id
}

\author{
Talitha V. Sahaly \\ Faculty of Law \\ Universitas Brawijaya \\ Malang, Indonesia \\ talithasahaly@yahoo.com
}

\begin{abstract}
The creation of Law Number 4 of Year 2009 on the Mining of Minerals and Coal (Indonesia Mining Law) has caused changes to occur in Mining Business Working agreement, turning them into Special Mining Business Licenses, which is quite significant and has brought up several issues. Several of these changes include, among others, forbidding companies who have Working agreement to conduct exports of concentrates, instead of requiring them to perform enrichment first; changes in the schema of tax obligations and royalties that must be paid by the company, wherein the company must follow general tax regulations that apply in Indonesia; changes in the areas of mining operations, becoming more restricted than before; and changes in the position of relationships of the company and the government.
\end{abstract}

These changes have raised quite serious reactions from several investors, in which PT Freeport Indonesia can be taken as an example. PT Freeport Indonesia has harshly reacted by rejecting the change from Working Agreements into Business Licenses and accusing Indonesia of having defaulted because of violating the principle of Pacta Sunt Servanda and will file a law suit through international arbitration. Meanwhile, Indonesia stands firm that it has the authority to regulate policies and politics within the country

Indonesia has provided several options regarding the changes in policy and adequate time to comply as a result of the enforcement of the Indonesia Mining Law.

Keywords-mining business working agreements, special mining business licenses, indonesian mining law

\section{INTRODUCTION}

Amendment of Law No. 1 of Year 1967 on Foreign Investment to Law Number 25 of Year 2007, as well as the is suance of Law Number 4 of Year 2009 on Minerals and Coal, have caused major changes to occur affecting all Working Agreements that have been arranged by the Government of Indonesia with several investors, both domestic and foreign ones (Contractors).

Working agreement (Kontrak Karya, KK) contains the rights and obligations of parties, such as the duty of Contractors who invest in a country that receives investment to fulfill matters that have been agreed upon by both parties, including the payment of royalties, taxes, rents, and others which have been described in the Working agreement. In return, the country also has obligations to fulfill, such as providing authority for the Contractor to operate mines [1], and the Contractors who made the Working agreement with the Government of Indonesia are under PT. Freeport Indonesia.

In 1991, the Working agreement between PT. Freeport Indonesia and the Government of Indonesia was signed. The is suance of Law Number 25 of Year 2007 and Law Nu mber 4 of Year 2009 have changed Working agreement into Special Mining Business Licenses (IUPK), wherein the law unilaterally converts holders of Working agreement to Special Mining Business Licenses and forbids the export of concentrates, unless purification takes place in advance. Yet, the export of concentrates is what has been done by PT. Freeport Indonesia from the start and as stated in the Working agreement[2].

Moreover, the law also changed the schemes of tax obligations and royalties that must be paid by the company, from what has been a clearly specified amount in the Working agreement to the one set by tax regulations that apply in Indonesia, and this was seen as a failure in providing legal certainty for PT. Freeport Indonesia. The area of mining operations was changed to be smaller than what was present in the Working agreement; another change is that initially in the Working Agreement, the position of the company and the government was level, but in the Business License, the government became positioned higher than the company.

These changes have raised quite serious reactions from several investors, one of them is PT Freeport Indonesia. PT Freeport Indonesia has harshly reacted by rejecting the change from Working agreement to Business Licenses and accusing Indonesia of having defaulted because of violating the principle of Pacta Sunt Servanda. This dispute ha brought to international arbitration against the state. Meanwhile, Indonesia stands firm that Indonesia has the authority to regulate policies and politics within the country..

\section{DISCUSSION}

A. Amendment of Law Number 11 of Year 1967 to Law Number 25 of Year 2007, and the Issuance of Law Number 4 of Year 2009

The following are several points regarding changes from Law Number 11 of Year 1967 on Foreign Investment to Law Number 25 of Year 2007 on Foreign Investment, and with 
the issuance of Law Number 4 of Year 2009, explained in the table below:

TABLE I. POINTS OF CHANGES FROM LAW NUMBER 11 OF YEAR 1967 TO LAW NUMBER 4 OF YEAR 2009

\begin{tabular}{|c|c|c|c|}
\hline No. & $\begin{array}{l}\text { Point of } \\
\text { change }\end{array}$ & $\begin{array}{c}\text { Law Number } 11 \text { of } \\
\text { Year } 1967\end{array}$ & $\begin{array}{c}\text { Law Number } 4 \text { of } \\
\text { Year } 2009\end{array}$ \\
\hline 1. & $\begin{array}{l}\text { Types of } \\
\text { mined } \\
\text { materials }\end{array}$ & $\begin{array}{l}\text { a) strat egic mined } \\
\text { materials; } \\
\text { b) vital mined } \\
\text { materials; } \\
\text { c) non-strategic and } \\
\text { non-vital mined } \\
\text { materials }\end{array}$ & $\begin{array}{l}\text { a) radioactive } \\
\text { minerals; } \\
\text { b) metals; } \\
\text { c) nonmetal and non- } \\
\text { stone minerals; } \\
\text { d) coal }\end{array}$ \\
\hline 2. & $\begin{array}{l}\text { Management } \\
\text { Authority }\end{array}$ & $\begin{array}{l}\text { a) strategic and vital } \\
\text { mined materials } \\
\text { by the Minister } \\
\text { b) vital and non- } \\
\text { strat egic non-vital } \\
\text { mined materials } \\
\text { by Level I } \\
\text { Regional } \\
\text { Governments }\end{array}$ & $\begin{array}{l}\text { a) Regent/Mayor for } \\
\text { their respective } \\
\text { Permitted Mining } \\
\text { Business Territory } \\
\text { (WIUP); } \\
\text { b) Governor if the } \\
\text { WIUP is located } \\
\text { across Regencies or } \\
\text { Cities; } \\
\text { c) Minister if the } \\
\text { WIUP is located } \\
\text { across Provinces }\end{array}$ \\
\hline 3. & Supervision & $\begin{array}{l}\text { Centered on the } \\
\text { Minister }\end{array}$ & $\begin{array}{l}\text { By the Minister, } \\
\text { Governor, Regent, } \\
\text { or Mayor according } \\
\text { to their authority }\end{array}$ \\
\hline 4. & $\begin{array}{l}\text { Mining } \\
\text { Regions }\end{array}$ & $\begin{array}{l}\text { There is no } \\
\text { detailed regulation } \\
\text { on mining } \\
\text { territories; } \\
\text { however, areas that } \\
\text { are off-limits such } \\
\text { as graveyards, } \\
\text { sacred places, } \\
\text { public works, } \\
\text { roads, rail lines, } \\
\text { water pipes, } \\
\text { electricity, gas, } \\
\text { housing, or } \\
\text { factories are } \\
\text { delineated }\end{array}$ & $\begin{array}{l}\text { a) Mining Business } \\
\text { Territory (WUP); } \\
\text { b) Public Mining } \\
\text { Territory (WPR); } \\
\text { c) National Reserve } \\
\text { Area (WPN). }\end{array}$ \\
\hline 5. & $\begin{array}{l}\text { Mining } \\
\text { Agreements }\end{array}$ & $\begin{array}{l}\text { a) Mining Authority } \\
\text { (KP); } \\
\text { b) Regional Mining } \\
\text { License (SIPD); } \\
\text { c) Public Mining } \\
\text { License (SIPR); } \\
\text { d) Working } \\
\text { Agreement (KK)/ } \\
\text { Working } \\
\text { Agreement for } \\
\text { Coal Mining } \\
\text { Business (PKP2B) }\end{array}$ & $\begin{array}{l}\text { a) Mining Business } \\
\text { License (IUP); } \\
\text { b) Public Mining } \\
\text { License (IPR); } \\
\text { c) Special Mining } \\
\text { Business License } \\
\text { (IUPK) }\end{array}$ \\
\hline 6. & $\begin{array}{l}\text { Mining } \\
\text { Business } \\
\text { Stages }\end{array}$ & $\begin{array}{l}\text { a) general } \\
\text { investigation; } \\
\text { b) exploration; } \\
\text { c) exploitation; } \\
\text { d) processing and } \\
\text { enrichment; } \\
\text { e) transport; } \\
\text { f) sale }\end{array}$ & $\begin{array}{l}\text { a) IUP for } \\
\text { exploration: } \\
\text { - general } \\
\text { investigation } \\
\text { - exploration } \\
\text { - feasibility study } \\
\text { b) IUP for operation } \\
\text { and production: } \\
\text { - construction } \\
\text { - mining } \\
\text { - processing and } \\
\text { enrichment } \\
\text { - transport and } \\
\text { sale }\end{array}$ \\
\hline
\end{tabular}

\begin{tabular}{|c|c|c|c|}
\hline 7. & $\begin{array}{l}\text { Duration of } \\
\text { License }\end{array}$ & $\begin{array}{l}\text { KP, KK, PKP2B } \\
\text { General } \\
\text { investigation: } 1 \\
\text { year + renewal of } 1 \\
\text { year. } \\
\text { Exploration: } 3 \\
\text { years + renewals of } \\
2 \text { x } 1 \text { year. } \\
\text { Feasibility study: } 1 \\
\text { year + renewal of } 1 \\
\text { year. } \\
\text { Construction: } 3 \\
\text { years. } \\
\text { Operation of } \\
\text { production: } 30 \\
\text { years + renewal of } \\
2 \text { x } 10 \text { years. }\end{array}$ & $\begin{array}{l}\text { a) IUP for } \\
\text { exploration of } \\
\text { metals: } 8 \text { years; } \\
\text { coal: } 7 \text { years; } \\
\text { b) IUP for operations } \\
\text { of mineral and } \\
\text { coal production: } \\
20 \text { years }+ \\
\text { renewals of } 2 \times 10 \\
\text { years. }\end{array}$ \\
\hline 8. & $\begin{array}{l}\text { Rights and } \\
\text { Obligations }\end{array}$ & $\begin{array}{l}\text { a) } \mathrm{KP} \text { : according to } \\
\text { regulations } \\
\text { b) } \mathrm{KK} \text { : regulated in } \\
\text { the contract }\end{array}$ & $\begin{array}{l}\text { According } \\
\text { regulations }\end{array}$ \\
\hline 9. & Divestment & Unregulated & $\begin{array}{l}\text { After } 5 \text { years of } \\
\text { production, holders of } \\
\text { IUP and IUPK with } \\
\text { foreign ownership } \\
\text { must divest stocks to } \\
\text { the country }\end{array}$ \\
\hline
\end{tabular}

Primary Data: processed

As mentioned in the "considerations" section of Law Number 4 of Year 2009, in regard to the economic growth of Indonesia, which affects the prosperity of the people of Indonesia, it should be that natural resources that are nonrenewable and affect the livelihood of the people of Indonesia must be controlled by the state, which leads to Law Number 4 of Year 2009 on Minerals and Coal being is sued.

Law Number 4 Year 2009 is an effort of the Government of Indonesia to secure and retake control of state-owned nonrenewable resources, which in this case is the resource of gold metal, as provided in Article 33 of the 1945 Constitution of Indonesia[3]:

... (2) Branches of production that are important to the state and govern the livelihood of the multitude are to be controlled by the state.

(3) Land, water, and the natural wealth contained therein are controlled by the state and are utilized for the greatest prosperity of the people.

The change from Law Number 11 Year 1967 to Law Number 25 Year 2007 and the is suance of Law Number 4 Year 2009 has brought about juridical implications to all Working agreement created by the Indonesian government, including that made by the Government of Indonesia with PT. Freeport Indonesia.

In a Special Mining Business License, the obligations of the Contractor are increased, by inclusion of the requirements to establish a place for the processing and enrichment of mined materials (smelter), to manage finances based on the accounting system in Indonesia, and to be obligated to pay taxes to the government. These changes have sparked harsh reactions from several Contractors, including PT. Freeport Indonesia. 


\section{B. Change of Working agreement to Special Business} Mining Licenses as a violation of the principle of Pacta Sunt Servanda

The fundamental change from Law Number 11 of Year 1967 to Law Number 25 of Year 2007 and the issuance of Law Number 4 of Year 2009 is the change of the status of Working agreement to Special Business Mining Licenses. Working agreement is made between the Government of the Republic of Indonesia and companies having legal entities in the state for foreign investment in conducting the mining activities such as excavating materials not including oil, natural gas, geothermal, radioactive materials, and coal[4]. Meanwhile, Special Business Mining Licenses are given by the Government to Contractors representing mining companies with Indonesian legal entities, state enterprises, regional enterprises, and private companies to conduct particular mining activities [5].

Working agreement contains the rights and obligations of the parties as a result of negotiation and agreement by the parties like with any contractual relationships in general. The parties concerned are the Government and the Contractor. The Contractor is defined as a private foreign company or a private foreign company that cooperates with a national company, followed by the establishment of legal entity to invest capital in the state to which the investment is addres sed[5].

The Working Agreement between PT. Freeport Indonesia and the Government of Indonesia is indeed a contract in private affairs with the purpose of obtaining economic benefits. As explained by Article 1654 of the Civil Code in regard to the state acting as a private legal entity, "All legal entities that are legally established, as well as private individuals, have the power to conduct civil actions, without undermining the regulations that change those powers..."

As such, the Working agreement has established a relationship between the Government and the Contractor that is equal or staat op gelijke voest al seen privaat person, as an equal relationship where the Government is not in an extraord inary position[6] or able to abandon the Working agreement [1]

In addition, in the Working agreement, there is a state of lex specialis, or special treatment that is given by the Government to the party of the Contractor. This special treatment means that all stipulations in the Working Agreement that have been agreed upon by both parties will never change due to regulations of law that generally apply (lex generalis)[7].

According to Law Number 4 of Year 2009, Working Agreements that are still applicable must be adjusted with those laws, as regulated in Article 169, letter b:

...stipulations designated in articles of working agreements and Working agreement of coal mining enterprises in letter a are adjusted no later than 1 (one) year from the time this Law is implemented, except in the case of state revenue.

The following is contained in the section of explanations: ...All articles contained in working agreements and working contracts of coal mining enterprises must comply with Laws.

The clause in Article 169 letter b implicates that both parties can no longer undertake investment activities based on the Working agreement, and instead, further activities of investment will be conducted based on the regulations determined by the Government of Indonesia, where the regulations are created by the Government of Indonesia on its own without agreement from Contractors including PT. Freeport Indonesia as a party

Meanwhile, it is known that every agreement binds the parties involved within, and each must be executed with good will. In Article 1338 of the Civil Code, it is stated that "all agreements that are legally created apply as laws for those who create them" or what is also called the principle of pacta sunt servanda. According to Article 26 of the Vienna Convention, pacta sunt servanda means that "every treaty in force is binding upon the parties to it and must be performed by them in good faith."

In this case, the party of PT. Freeport Indonesia and the party of the Government of Indonesia are bound in a working agreement that was agreed upon before the creation of Law Number 4 of 2009. However, the Government of Indonesia then issued new regulations for Working agreement and demanded parties that still possessed them to adjust to the contents of the new regulations.

A Working agreement is a contract that binds the parties that agree upon them, and thus any changes that are related to the contract certainly must be based on all parties for which the contract is concerned. In such conditions, it can thus be said that the Government of Indonesia had violated the principle of pacta sunt servanda.

\section{Change in Working agreement to Special Business Mining Licenses Seen from the Sovereignty of Indonesia as the Host Country}

According to the doctrine of restrictive state immunity, in certain conflicts, a country possesses immunity from court jurisdiction. In relation to these specific conflicts, the actions of a country may be differentiated as either "Juri imperii" which means actions of the state that are purely related to the sovereignty of the state ${ }^{1}$ and "Jure gestiones" which means actions of the state that are related to commerce ${ }^{2}$, which can be described as Commercial Acts [8].

As mentioned in the previous section, the Working Agreement between PT. Freeport Indonesia and the Government of Indonesia is indeed a contract in private affairs. Even so, the Govern ment of Indonesia as one of the parties in the Working Agreement is a representation of the country of Indonesia, as a state as well a public agency that is independent and sovereign, possesses regional sovereignty, and executes rights and obligations for the major part of the prosperity of its people, cannot be cast aside, including in issuing Law Number 4 of Year 2009.

Although the government in its capacity as a private legal entity does not possess immunity from court jurisdiction, a state still possesses the sovereignty to protect and control natural resources present in its territory for the greatest

1 The State in the scope of Juri imperii is when the State conducts actions in the public realm; immunity is possessed by the State, and thus its actions cannot be tried in a foreign court, and the State is a regulator in its stat us as a sovereign state.

2 The State in the scope of Jure gestiones is when the State conducts civil actions. The State leaves behind its immunity of affairs in the civil realm, and can thus be tried in a judicial body, and the principle of equality of the parties applies to the State and other parties in the civil affairs. 
interests of the people of Indonesia. In other words, in addition to acting as a private legal entity, the state also acts as a public legal entity. As explained by Professor Hikmahanto Juwana from Universitas Indonesia, “...Freeport has wrongly aligned the Indonesian government as an equal. The issue is that the position of the government exists in two dimensions.[9]."

In addition to reasons of sovereignty and the obligation of the state to protect the greatest interests of its people, from the results of audit by the Financial Supervisory Agency (BPK), in particular related to the Working agreement between PT. Freeport Indonesia and the Government of Indonesia, in the period from 2009 to 2015 , it was found that "...the potential for a deficit of fixed contributions and state royalties accounts for US\$ 445.96 millions or Rp. 6.02 trillions (at a rate of 13,500), in addition to the potential for the delay of added mineral value of US\$135.094 due to the enrichment facility (smelter) being delayed in construction[10].

Furthermore, there are also state losses from the environmental standpoint, as the location of mining activities conducted in a protected forest requires a Forest Area Lending and Usage Permit (IPPKH), whereas PT. Freeport Indonesia is one of 13 mining companies without such a permit. As a result, Indonesia loses a revenue potential as part of the sources of state revenue. Thus in this case the state has the right to conduct such actions for the simple reason of making up for the economic and environmental losses that are suffered by the state, wherein this would affect the livelihood of the people of Indonesia.

Pacta sunt servanda has the purpose of becoming a guarantee of legal certainty of a binding contract and to avoid the confusion that occurs when one or both parties to a contract possesses bad faith, arbitrarily withdraws itself from a contract, or violates the obligations that have been agreed upon in a contract.

As such, pacta sunt servanda has the purpose of providing the value of a contract itself. When there are parties that create an agreement, but nothing exists to provide value for the binding of that agreement, the agreement will become futile and be of no value; thus, the agreement cannot be called as a contract when its basic value does not exist, which is to bind the parties involved in it.

Arguments on the limits of the principle of pacta sunt servanda have raised debates from time to time, in particular in the area of international law. There is a question that is frequently asked, which regards how a country can disregard its obligations in executing an agreement, or in this case a contract, when circumstances change. This question becomes harder to answer because there is a legal "freeze" clause in an agreement, wherein this clause means that both parties agree to adopt and be consistent regarding applicable laws at the time the agreement was decided upon, and both parties are not subject to any changes in regulations that may occur[11].

Pacta sunt servanda is indeed the primary principle in the creation of agreements, both private and public. However, in fact, pacta sunt servanda is not absolute in nature; this primary principle even has a certain limit. This is found in International Law Commission Article about Responsibility of States for Intermationally Wrongful Acts 2001, on Necessity[12]:
Necessity may not be invoked by states as a ground for precluding the wrongfulness of an act not in conformity with an international obligation of that State unless the act:

a) is the only way for the State to safeguard an es sential interest against a grave and imminent peril; and;

b) does not seriously impair an essential interest of the State of States towards which the obligation exists, or of the international community as a whole.

Necessity, as an inevitable requirement, can become a reason for justification for violating a law as conducted by a country. Here, the necessity pertains to when the necessity is the only way for a country to defend or secure its fundamental interest from a threat that may appear. As well, the action that is taken on the basis of that necessity does not weaken the fundamental interests of existing obligations of the country, or toward the international community as a whole.

The is suance of Law Number 4 of 2009 replacing Law Number 11 of Year 1967, as well as the issuance of the Law on Minerals and coal is an effort of the Government of Indonesia to secure and retake control of non-renewable resources that belong to the state, which in this case is the mineral resource of gold (according to Article 33 of the 1945 Constitution), as well as the results of BPK audit, become a necessity for the greatest interests of the people.

Thus the change from Working agreement to Special Business Mining Licenses, as a juridical implication of regulatory changes in the field of investment, mining, and coal and minerals, is not merely seen as a violation of the principle of pacta sunt servanda where the party of the Indonesian state has shown good will by providing compensation of time for adjustment and opening opportunities for further negotiation with Contractors including PT. Freeport

\section{Head of Agreement between the PT Freeport Indonesia and the Indonesian Government}

There are two actions taken by PT. Freeport Indonesia as a response to the change of the laws, which are the creation of a Memorandum of Understanding (MoU) with the Govern ment of Indonesia on July 25, 2014, and the creation of a Head of Agreement (HoA) on July 12, 2018.

Among the points in the MoU is the following statement: "The Parties will negotiate a Revised Working Agreement that contain the changes in regulations regarding Working Agreement Area, State Revenue, Domestic Processing and Refinement, Divestment, and the Employment of Local Labor..." Another point of discussion is related to the divestment of $51 \%$ of stocks to the Government Indonesia. However, this has not yet happened.

On July 12, 2018, PT. Freeport Indonesia created a Head of Agreement (HoA) with the same points of discussion as the previous MoU, one of which is the divestment of $51 \%$ of stocks to the Government Indonesia. The HoA was created between PT. Freeport Indonesia and a state-owned enterprise that would purchase the stocks, which is PT. Indonesia As ahan Alumunium (Inalum)[13].

The MoU between PT. Freeport Indonesia and the Government of Indonesia contains a clause with the 
statement "The Parties admit that this Notice of Agreement does not eliminate the rights and obligations of the Parties as noted in the Working Agreement.[14]." Thus with the creation of the MoU, PT. Freeport Indonesia is judged to have not adjusted to the new obligations as regulated in Law Number 4 of 2009.

Next, in the HoA it is mentioned that "....announced today that it has entered into Heads of Agreement with the Indonesian state-owned enterprise PT Indonesia Asahan Aluminium...under the terms of the non-binding Heads of Agreement, Inalum will acquire for cash consideration...[15]" . As such, the nature of the HoA is non-binding, which means that the HoA has no legal consequences of any kind for both parties, except as an early understanding for agreements to come in the future. In any case, the HoA between PT. Freeport Indonesia becomes the basis of an agreement regarding the divestment of stocks, which will later on be agreed upon by the parties of PT. Freeport Indonesia and the Govern ment of Indonesia through PT. Inalum.

This HoA is the final stage before entry into the actual agreement[16]. Thus, although fundamentally the HoA that was agreed is currently not binding, the HoA functions to ensure the percentage of stocks to be divested, which is to be stated in a Joint Venture Agreement and executed thereafter.

\section{CONCLUSION}

The action of the Government of Indonesia in changing Law Number 11 of Year 1967 to Law Nu mber 4 of 2009 and the issuance of the Law of Minerals and Coal, causing the juridical implication of changing Working agreement to Special Mining Business Licenses that place the burden of new obligations to the Contractor, can be justified according to international law.

The results of audit by the BPK and efforts by the Government of Indonesia to secure and retake control of non-renewable resources belonging to the state, which in this case is gold, as established in Article 33 of the 1945 Constitution of Indonesia, become the reason and this fulfills the criteria of necessity or an inevitable requirement of Indonesia in the attempt to provide the greatest pros perity for the people

The presence of alternatives in the form of time compensation for adjustment and opening the opportunity for further negotiation to the Contractors, including to PT. Freeport, realizes the good will of the Government of Indonesia to the Contractors of Working agreement.

\section{ACKNOWLEDGMENT}

This paper is developed from the results of results of research by Talitha V. Sahaly, written as the Final Assignment for the Undergraduate Program, Faculty of Law, Universitas Brawijaya, Malang, Indonesia, which is planned to become the starting point for further research.

\section{REFERENCES}

[1] Nanik Trihastuti, Hukum Kontrak Karya [Law of Working Agreements].Malang: Setara Press, 2013.

[2] Law Number 4 of 2009 on Mineral Mining and Coal. Indonesia, 2009.

[3] The 1945 Constitution of the Republic of Indonesia. 1945.

[4] Minister of Energy and Mineral Resources, Article 1 of the Decree of the Minister of Energy and Mineral Resources Number 1614 of Year 2004 on the Guidelines of Processing Requests for Working Agreements for Mining Enterprises of Foreign Investment. Indonesia, 2004.

[5] Law Number 4 of 2009 on Investment. Indonesia, 2009.

[6] Indroharto, Peradilan Tata Usaha Negara [State Administration Court]. Jakarta: Pustaka Sinar Harapan, 2013.

[7] Abrar Saleng, "Kepastian Hukum dan Status Hukum Pemerintah dalam Kontrak Karya Pertambangan [Legal Certainty and Legal Status of the Government in Mining Working Agreements]," Mimbar Hukum. Vol. X, 2000.

[8] Huala Adolf, Aspek-apek Negaradalam Hukum Internasional [Aspects of the State in International Law] . Jakarta: Rajagrafindo.

[9] Srihandriatmo Malau, "Ancaman Freeport ke Arbitrase Bentuk Arogansi Merasa Sejajar Dengan Pemerintah Indonesia [Threat of Arbitration by Freeport as a Form of Arrogance of Being Equal to the Government of Indonesia]," 2017. [Online]. Available: http://www.tribunnews.com/nasional/2017/02/21/ancaman-freeportke-arbitrase-bentuk-arogansi-merasa-sejajar-dengan-pemerintahindonesia?page=all. [Accessed: 19-Jul-2018].

[10] “Audit Keuangan: Potensi Kerugian Kontrak Karya Freeport [Financial Audit: Potential of Losses from the Freeport Working Agreement," Warta BPKEdition 10-Vol.VII, 2017.

[11] Christina Binder, The Limits of Pacta Sunt Servanda in International Law. Band 245, 2013

[12] Draftarticles on Responsibility of States for Internationally Wrongful Acts 2001. .

[13] PT . Freeport Indonesia, "Kesepakatan Pokok Menjamin Keberlangsungan dan Stabilitas Operasi PT Freeport Indonesia [Fundamental Agreement Ensuring the Continuity and Stability of Operations of P T Freeport Indonesia]," PT. Freeport Indonesia, Press Conference, 2018. [Online]. Available: https://ptfi.co.id/media/files/press/5b47336a09da9_siaran_pers_kese pakatan_pokok_menjamin_keberlangsungan_dan_stabilitas_operasi _pt_freeport_indonesia.pdf. [Accessed: 19-Jul-2018].

[14] Memorandum of Understanding Between Directorate General of Mineral and CoalThe Ministry of EnergyandMineral Resources and PT Freeport Indonesia on Adjustment of The Contract of Work. 2018.

[15] Freeport-McMoRan Inc., "Freeport-McMoRan Announces Terms Of PT Freeport Indonesia Divestment And New Long-Term Partnership With PT Inalum." [Online]. Available:

https://investors.fcx.com/investors/news-releases/news-releasedetails/2018/Freeport-McMoRan-Announces-Terms-of-PT-FreeportIndonesia-Divestment-and-New-Long-Term-Partnership-with-PTInalum/default .aspx. [Accessed: 19-Jul-2018].

[16] Nufransa Wira Sakti, "Divestasi Saham Freeport untuk Siapa? [Divestment ofFreeport Stocks, for Whom?],"2018. [Online]. Available:

https://nasional.kompas.com/read/2018/07/20/12081371/divestasisaham-freeport-untuk-siapa. [Accessed: 22-Jul-2018]. 